\title{
The Implementation Of Information Technology In The Development Of Left And Right Brain At An Early Age In The World Of Education
}

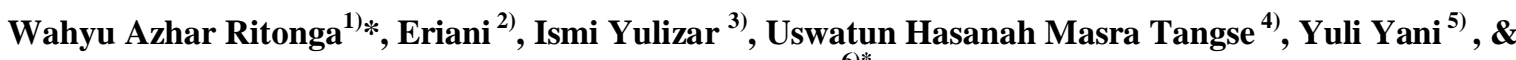 \\ Dwina Putri $\left.{ }^{6}\right)^{*}$ \\ ${ }^{1)}$ Teknik Informatika, Fakultas Teknik, Universitas Al Washliyah Labuhanbatu
${ }_{2,3,4,5,6)}$ Pendidikan Islam Anak Usia Dini , Sekolah Tinggi Ilmu Tarbiyah Al- Bukhary Labuhanbatu
}

*Coresponding Author

Email :wahyuazharrit@gmail.com

\begin{abstract}
The purpose of the study is to develop the use of the right and left brain in early childhood through the implementation of information technology in this case learning using video with words. Education in learning that is done must keep up with the times by utilizing information technology we often mention with the era of revolution 4.0. Research methods use descriptive qualitative methods by means of observation and interview of teachers, Then the data obtained in the test using spss for windows with a population of 60 early childhood results obtained $F_{\text {count }}=23,347>F_{\text {table }}=3.16$ so it can be said that the implementation of information technology in learning in the form of video display is very good in the development of the right and left brain in each individual early childhood.
\end{abstract}

Keywords: Implementation, Information Technology, Right and left brain, Education and SPSS for windows.

\section{INTRODUCTION}

With the development of an increasingly technological era is very influential on all sectors of the economy, tourism especially education, this does not rule out the possibility that we all must continue to exist and continue to compete in adding scientific insights to make superior human resources to indonesia gold in 2045. The condition of the living environment also greatly affects one's education regarding the knowledge gained, this is because the limitations of learning media tools are very vulnerable, not to mention parents who lack knowledge about the importance of education for their children and the education system is very lacking in obtaining information about knowledge of early childhood which has a very big influence on the development of mindsets, especially realistic thinking in responding to something that happens in everyday life. In education the past is different from the present which can be seen from the differences in socio-cultural environment. (Sigit \& Laili. 2020) Information technology is evolving into a media tool in the development of knowledge of right brain and left-brain mindsets. Education that is cultivated is nothing but a special character beginning in early childhood as an effort to instill commendable behavior in children, both behavior in worship, behavior as a good citizen, behavior of interacting with others and the environment, and commendable behavior that is beneficial for his life success. (Khaironi. 2017) In this case, efforts are made to develop character by activating the right and left brain in learners, especially PIAUD. Early childhood is an innocent human being and has potential that still has to be developed. Children have certain characteristics that are distinctive and not the same as adults and will develop into a whole human being. (Wena, dkk. 2021).

Man was created by God, there is a part of the brain in our head. The big brain and the cerebellage. The cerebrain is divided into the right hemisphere and the left hemisphere. The 
right hemisphere of the brain in the world of health is called the right helispher. As the name suggests, the right hemisphere is the anatomically located part of the right hemisphere that regulates all activities, as well as the health of the right hemisphere, and is also responsible for the right body. (Tejahtc, 2022). So that in the world of education for an early age it needs to continue to be strived in activating the left and right brain so that activities carried out using information technology are the use of media in learning used or display in the form of video images and words or sentences. So it will train early childhood actively using the right brain and left brain, In this video it is necessary to display images in storytelling using cartoon images so that it can be said that the ability to tell stories is one way that children can communicate with their peers which in this case will be applied in the school environment of early childhood education. (Karnemi, 2021). At the time of this pandemic learning activities must still be done either online or offline, although the online learning process must also be able to continue to improve cognitive development in children as well as in face-to-face learning (offline) to be able to improve children's cognitive development. (Candra, dkk. 2022) The application of critical literacy should not only be focused on higher education but also on early childhood education as early childhood grows in the technological era which is certainly influenced by the modernization of technology and human civilization. (Aulia, Hidayat dkk., 2021)

\section{RESEARCH METHODS}

The research method used is descriptive qualitative by means of observation and interviews in this case the observation is done by looking at the behavior of activities carried out by early childhood education children in the object of this research data on the implementation of the method of playing pictures and words in the learning videos presented and interviews to improve the process. learning using information technology in this case learning using video playback. the location is carried out in an early childhood education school.

\section{RESULTS AND DISCUSSION}

Learning using digital systems is very much a benefit that provides learning with satisfying interactions and offers many opportunities for learners to learn to use the sense of vision, sounding and neural balance of the brain that is active in the learning process using video while doing or practicing. (Manesis, 2020). The implementation of information technology in the development of the left and right brain in early childhood in the world of education by using information technology especially in early childhood, the use of digital systems is very effective with video display learning because it seems they are in their activities and activities in their environment. With the appearance of video-based learning, inevitably the nerves of the right and left brain of early childhood will be active. So that the use of digital systems continues to be developed with video content collaborating related to behavior and how to speak on the video.

Information technology that is currently used wisely and continues to monitor video content is very good for development in early age participants. 


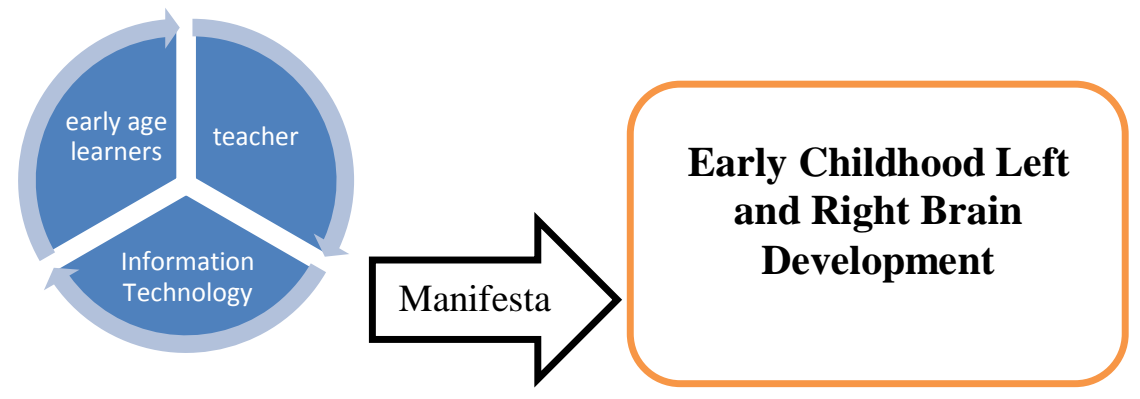

Figure 1. Left and Right Brain Development Cycle

Figure 1. It is seen that early childhood learners, teachers and technology are one unit that is interconnected or related in the development of the left and right brain. If the use of communication technology is used with good assistance and supervision, it is very efficient in the formation of the use of activities using the left and right brain. Media that have now entered the digital era inevitably we have to innovate learning for an early age so that their right and left brains can develop. With a variety of fun and exhilarating video views so that they are active.

Table 1. Model Summary

Model Summary

\begin{tabular}{|c|c|c|c|c|c|c|c|c|c|}
\hline \multirow[t]{2}{*}{ Model } & \multirow[t]{2}{*}{$\mathrm{R}$} & \multirow[t]{2}{*}{ R Square } & \multirow{2}{*}{$\begin{array}{l}\text { Adjusted R } \\
\text { Square }\end{array}$} & \multirow{2}{*}{$\begin{array}{l}\text { Std. Error of } \\
\text { the Estimate }\end{array}$} & \multicolumn{5}{|c|}{ Change Statistics } \\
\hline & & & & & $\begin{array}{l}\text { R Square } \\
\text { Change }\end{array}$ & F Change & df1 & df2 & $\begin{array}{l}\text { Sig. F } \\
\text { Change }\end{array}$ \\
\hline 1 & $.536^{\mathrm{a}}$ & .287 & .275 & 2.534 & .287 & 23.347 & & 58 & .000 \\
\hline
\end{tabular}

a. Predictors: (Constant), Left and Right Brain

Tabel 2. Hasil Anova

ANOVA $^{\mathrm{a}}$

\begin{tabular}{|c|c|c|c|c|c|c|}
\hline \multicolumn{2}{|c|}{ Model } & Sum of Squares & $d f$ & Mean Square & $\mathrm{F}$ & Sig. \\
\hline & Regression & 149.930 & 1 & 149.930 & 23.347 & $.000^{b}$ \\
\hline 1 & Residual & 372.470 & 58 & 6.422 & & \\
\hline & Total & 522.400 & 59 & & & \\
\hline
\end{tabular}

a. Dependent Variable: Implementation of Information Technology

b. Predictors: (Constant), Left and Right Brain

From the results of data using spss for windows obtained that very significant influence of information technology implementation on the development of the left and right brain of early childhood with a value of Fhitung $=23,347$ and Ftabel $=3.16$ with a sample of 60 , So it can be concluded that the significant influence between the implementation of technology and the development of the left and right brain of early childhood. Based on research, learning using video-based information technology is very good for changes that occur in the ability to speak and behave well and in accordance with Permendikbud Number 137 of 2014 which contains early childhood to be able to express their language, by means of children being able to ask questions, answer questions, and communicate verbally, so that they can retell what is 
known, can learn pragmatic language, express feelings, ideas and desires of children in the form of scribbles or behavior that uses the left and right brain.

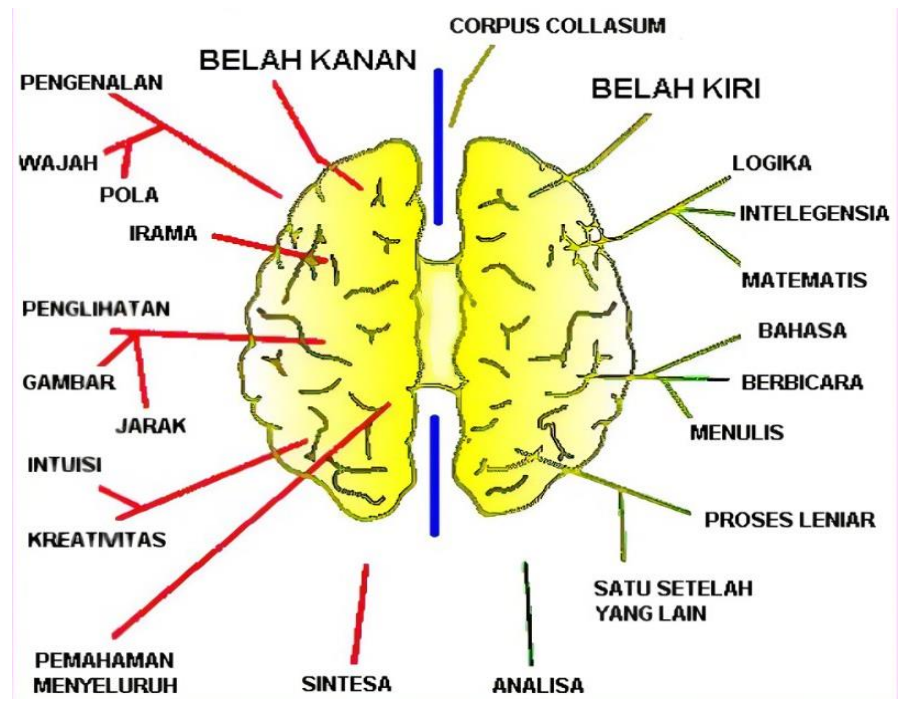

Figure 2. Certain Functions of the Human Brain Pattern (WordPress.com)

Based on figure 2 we can see that the human brain is the source of all activities with as the center of human control itself so that the need to continue training to improve the mindset especially realistic thinking because there is such a giant human brain with so many nerves that exist that all must be maximized. Early childhood is still in the process of receiving from what they see and hear very easily change mindset and behavior.

\section{CONCLUSION}

By using communication technology in the learning process, especially in the development of the right brain or EQ (Emotional Quatient), in this case including socialization, communication, emotional control as well as intuitive, body expression and creativity. For the left brain closely to IQ (Intelligence Quatient), such as the ability to read, write, memorize, calculate, logic and ratios. With the implementation of information technology through videobased learning so that by directly early childhood students use both their brains so that if this part of the brain is used in a balanced manner then individual students will be effective in their daily activities both sociable and intelligence attached to their brains.

\section{REFERENCES}

Dedeh, K., Debibik, N., F., \& Rina. S. (2021). Implementation of Storytelling Methods Against Language Skills of Children Aged 4-5 Years in Paud Sahabat Rawamerta Subdistrict. Pratama Widya: Journal of Early Childhood Education, 6(2): 152-158

Mulianah Khaironi (2017). Early Childhood Character Education. Hamzanwadi University's Golden Age Journal, 01 (2): 82-89 
Raden, A., U., H., Paridah, H., \& Siti, H. (2021). Knowledge and Understanding of Early Childhood Islamic Education Teachers (PIAUD) on Critical Literacy in Indonesia. Al Athfaal: Scientific Journal of Early Childhood Education. 4 (2): 198-212

Sigit Purnama \& Laily Hidayati. (2020). Early Childhood Parenting in Indraputra Saga. Journal of Obsession: Journal of Early Childhood Education 4 (2): 520-542

Tejahtc (2022). Understanding the Right Brain, Structure, Function and How It Works. https://sel.co.id/otak-kanan/ tanggal 5 januari 2022

Wena, P., Subawa, P., \& Suparya, K., (2021). Improvement of Children's Fine Motor Development Through Finger Painting Activities Group A Tk Weda Purana Pemaron. Pratama Widya: Journal of Early Childhood Education 6(2): 110-116

Yuliska Candra., A. P., Anisa, Siska., A. Siti.A.,I., dkk (2022). Utilization of Smart Boards for Early Childhood Cognitive Development in Ra-Al Jihad Lubuk Aur Kec. Bayang Kaab. South Coast prov. West Sumatra. Childhood Education: Journal of Early Childhood Education. 3 (1): 16-20

Certain functions of the human brain https://kampus.unikom.ac.id/s/userassets/10509553/blog_images/image_56205c01bca8 d509f889229ca3a22a97.jpg. tanggal 03 januari 2021 